\title{
STRATEGI DAN PROGRAM PURI SAYAN SEBAGAI DAYA TARIK WISATA HERITAGE DI DESA SAYAN, KECAMATAN UBUD, KABUPATEN GIANYAR, BALI
}

Ratih Arthanovia a, 1, I Made Adikampanaa, 2

1 ratihamardita@gmail.com 1, 2 adikampana@unud.ac.id

a Program Studi S1 Destinasi Pariwisata, Fakultas Pariwisata,Universitas Udayana, Jl. Dr. R. Goris, Denpasar, Bali 80232 Indonesia

\begin{abstract}
This study focuses on studying the planning of Puri Sayan Ubud as a heritage tourist attraction in Sayan Village, which is also intended to realize one of the Village missions, namely to become a Tourism Village in order to improve the welfare of local communities. This study has a limited scope in identifying existing conditions of tourism in Puri Sayan and Puri Sayan planning as a heritage tourist attraction. The data collection techniques in this study are observation, interviews, and documentation. Data analysis techniques used are qualitative descriptive and SWOT analysis that refers to tourism product components $4 A$. The results of this study are in the form of strategies and programs produced by SWOT analysis after identifying existing conditions that refer to tourism product components $4 A$.

The results of this study is about the main planning of Puri Sayan Ubud as an Attraction of Heritage Tourism by designing various programs such as attraction and management that are designed based on the strategy of the result of SWOT analysis that has been done.
\end{abstract}

Key Word: Heritage, Heritage Tourism, Planning, Puri

\section{PENDAHULUAN}

Indonesia dengan keanekaragaman budaya, kekayaan alam serta keramah-tamahan penduduknya merupakan potensi dalam kepariwisataan. Salah satu daerah tujuan wisata yang sangat terkenal dari Indonesia adalah Bali. Bali terkemuka di dunia memiliki berbagai potensi yang menunjang pertumbuhan kepariwisataan. Perkembangan kepariwisataan di Bali kini telah mengalami kemajuan pesat baik dari segi kuantitas maupun kualitas (Hariyana dan Mahagangga, 2015).

Saat ini beberapa desa di Bali sedang gencar membangun dan mengembangkan kegiatan pariwisata lokal. Salah satu desa yang sedang melakukan hal tersebut adalah Desa Sayan, Kecamatan Ubud, Kabupaten Gianyar. Desa Sayan kini masih dalam upaya pengembangan sebagai desa wisata.

Upaya pengembangan Desa Sayan sebagai desa wisata dilatarbelakangi oleh adanya berbagai potensi yang dimiliki oleh desa ini. Potensi yang dimiliki desa ini tiga di antaranya yang paling menonjol adalah wisata water tubbing, wisata alam bija dan Puri Sayan sebagai daya tarik wisata heritage. Dalam besarnya pengaruh kebudayaan di Bali sebagai faktor datangnya wisatawan, maka Puri Sayan tentunya akan berpotensi menjadi daya tarik wisata yang kuat. Mengenai hal tersebut, penting dilakukan penelitian tentang strategi dan program Puri Sayan sebagai daya tarik wisata heritage.

Beberapa alasan yang membuat Puri Sayan patut dijadikan sebagai wisata heritage, di antaranya adat istiadat yang masih terjaga, dan bangunan asli peninggalan zaman kerajaan ubud dengan nilai sejarah di dalamnya. Puri Sayan juga memiliki luas tanah yang cukup memadai untuk menggelar acara kesenian serta berada pada lokasi yang strategis. Hal tersebut memberikan peluang bagi Puri Sayan sebagai wisata heritage guna mendukung perkembangan Desa Sayan sebagai desa wisata.

Adapun telaah hasil penelitian sebelumnya atau tinjauan pustaka yang akan digunakan untuk menjadi acuan dalam penelitian yaitu oleh Dinov Sambadi Adistria Laksana pada tahun 2018 mengenai Strategi Pengemasan Wisata Heritage di Desa Wisata Kerta, Kecamatan Payangan, Kabupaten Gianyar dengan metode serupa dengan penelitian ini yaitu deskriptif kualitatif namun didapati perbedaan dalam lokasi penelitian. Kemudian penelitian yang telah dilakukan oleh I.B. Agung tahun 2010 tentang Strategi Pengembangan Puri Agung Karangasem sebagai Daya Tarik Wisata Budaya di Kabupaten Karangasem dengan menggunakan teknik analisis SWOT yang dijadikan acuan dalam penelitian yang dilakukan oleh peneliti ini. Selanjutnya penelitian yang dilakukan oleh Arichtia Praevianti Taolin pada tahun 2016 tentang Potensi Heritage yang dimiliki oleh Desa Wisata Tamkesi Kabupaten Timor Tengah Utara sebagai Daya Tarik Wisata dimana penelitian ini berfokus pada strategi pengembangan pariwisata pusaka pedesaan di Desa Wisata Takemsi Kabupaten Timor Tengah Utara sebagai tujuan wisata.

Penelitian ini menggunakan Konsep Perencanaan (Inskeep, 1991), Konsep Komponen Produk Pariwisata (Cooper, 1995: 81) yang dalam penelitian ini digunakan sebagai indikator dalam menganalisis SWOT. Kemudian Konsep Potensi (Pendit, 1999) guna untuk meninjau potensi yang dimiliki Desa 
Sayan yang nantinya dapat dikembangan sebagai atraksi di Puri Sayan itu sendiri. Dalam penelitian ini juga menggunakan tinjauan mengenai puri (Putra Agung, 2001) serta tinjauan wisata heritage (Spillane, 1987) yang dimaksudkan untuk merancang Puri Sayan sebagai sebuah warisan budaya yang memiliki nilai sejarah sebagai sebuah pariwisata pusaka yang diminati wisatawan. Konsep dan tinjauan tersebut akan menjadi pisau analisis dalam memilah data-data yang telah dikumpulkan oleh peneliti.

Artikel ini mengkaji Strategi dan program Puri Sayan sebagai daya tarik wisata heritage di Desa Sayan yang juga diperuntukan untuk mensejahterakan dan meningkatkan perekonomian masyarakat lokal.

\section{METODE PENELITIAN}

Penelitian ini dilakukan di Puri Sayan yang berlokasi di Desa Sayan, Kecamatan Ubud, Kabupaten Gianyar. Penelitian berlangsung selama kurang lebih 2 bulan sejak awal Maret hingga akhir April 2019. Ruang lingkup permasalahan dalam penelitian ini, adalah strategi dan program Puri Sayan sebagai Daya Tarik Wisata Heritage. Strategi dan program produk wisata Heritage ini dihasilkan dengan menggunakan metode analisis SWOT yang mengacu pada komponen produk pariwisata 4A di Puri Sayan, Desa Sayan, Ubud, Gianyar. Program dalam penelitian ini adalah komponen produk pariwisata heritage di Puri Sayan sebagai daya tarik wisata Heritage. Data primer (Moleong, 2007) yang diperoleh dari fakta-fakta langsung di tempat penelitian, diambil dan diolah sendiri dari Puri Sayan dengan metode wawancara, obeservasi serta dokumentasi. Data sekunder (Sugiyono, 2007) yang terdapat dalam penelitian ini adalah data yang diperoleh dari buku-buku kepustakaan dan website yang memiliki informasi terkait Puri Sayan dan Desa Sayan.

Teknik pengumpulan data yang digunakan antara lain observasi (Bungin, 2003), wawancara (Moleong, 2007), dan dokumentasi (Bungin, 2003). Adapun data yang diperoleh yaitu kondisi eksisting Desa Sayan dan Puri Sayan menurut pengamatan peneliti secara langsung ke lokasi penelitian serta menurut narasumber yang menjadi terwawancara dalam penelitian ini. Data yang diperoleh dari metode dokumentasi yaitu profil desa untuk gambaran umum serta sejarah desa dan Puri Sayan. Teknik analisis data yang digunakan dalam penelitian ini adalah analisis deskriptif kualitatif (Moleong, 2007). Dalam analisis di penelitian ini juga digunakan pendekatan SWOT (Rangkuti, 2002 : 3) dengan mengacu pada konsep komponen pariwisata 4A (Cooper, 1995: 81) untuk mengkaji potensi yang dimiliki oleh Puri Sayan sebagai daya tarik wisata Heritage.

\section{HASIL DAN PEMBAHASAN}

A. Kondisi eksisting pariwisata Puri Sayan berbasis komponen produk pariwisata

Dalam hal ini akan dibahas mengenai Kondisi Eksisting Desa Sayan agar mengetahui seperti apa kondisi eksisting di Desa Sayan dengan meninjaunya menggunakan konsep komponen produk pariwisata 4A yaitu Attraction, Accessibility, Amenity, dan Ancillary. Adapun kondisi eksisting Desa Sayan yang dimaksud adalah sebagai berikut:

\section{Attraction}

Desa Sayan memiliki 3 potensi utama yang ingin dikembangkan untuk dijadikan Daya Tarik Wisata guna mewujudkan misinya yakni menjadi Desa Wisata. Tentunya untuk menjadi Desa Wisata, Desa Sayan memerlukan Strategi dan program yang matang untuk mengembangkan suatu potensi agar dapat menjadi penyokong utama berdirinya Desa Wisata pada Desa Sayan. Potensi utama tersebut antara lain adalah yang pertama yaitu wisata alam bija, yang kedua adalah water tubbing, serta yang terakhir adalah Puri Sayan. Puri Sayan merupakan salah satu Puri di Desa Sayan yang dapat dikatakan memiliki keunikan tersendiri.

Desa Sayan memiliki ide untuk mengembangkan Puri Sayan sebagai daya tarik wisata karena kebudayaan merupakan hal yang kental bagi masyarakat Bali khususnya di Ubud. Puri Sayan merupakan "anak" daripada Puri Ubud atau dapat dikatakan masih kuat hubungannya dengan Puri Ubud. Hal ini dikarenakan penghuni kerajaan di Puri Sayan merupakan bagian dari keluarga di Puri Ubud. Dapat dilihat juga dari Upacara Ngaben di Puri Ubud yang dihadiri oleh penghuni Puri Sayan.

Gambar 1. Gerbang Puri Sayan

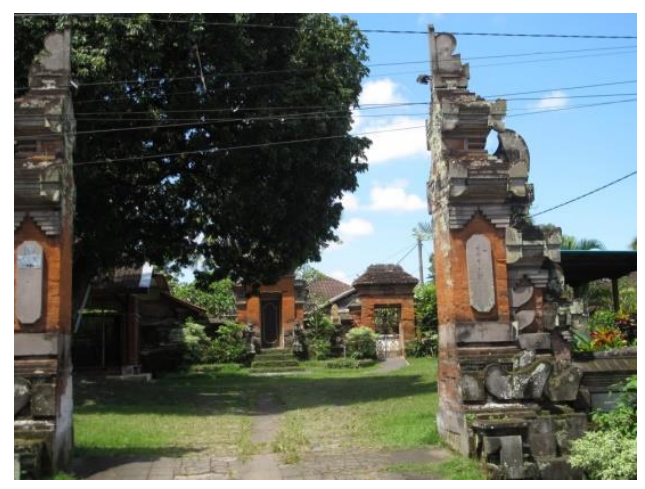

(Sumber : Dok. Penelitian, 2019)

Puri Sayan memiliki kondisi fisik yang unik, tentunya juga memiliki nilai sejarah yang tinggi. Hal 
ini merupakan daya tarik tersendiri yang dimiliki oleh Desa Sayan. Keunikan kondisi fisik Puri dapat dijadikan peluang untuk menjadikan Puri sebagai akomodasi di Desa Sayan. Jika nantinya Desa Sayan menjadi Desa Wisata maka akan lebih unik dan memiliki ciri khas bahwa akomodasi yang dimiliki adalah sebuah Puri.

Walaupun Puri Sayan tidak seluas Puri Agung Ubud, namun dengan berada di dalamnya saja nuansa akan sejarah kerajaan pada Puri dapat terasa. Bapak Tjokorda Gede, penghuni Puri selaku Bendesa Adat di Desa Sayan mengatakan bahwa Puri Sayan sangat berpotensi untuk dijadikan daya tarik wisata heritage. Adapun peninggalan selain bangunan tua nan bersejarah itu daripada Puri Sayan adalah Lontar Puri yang juga rutin di sembahyang kan pada upacara adat.

\section{Gambar 2. Persembahyangan Lontar di Puri Sayan}

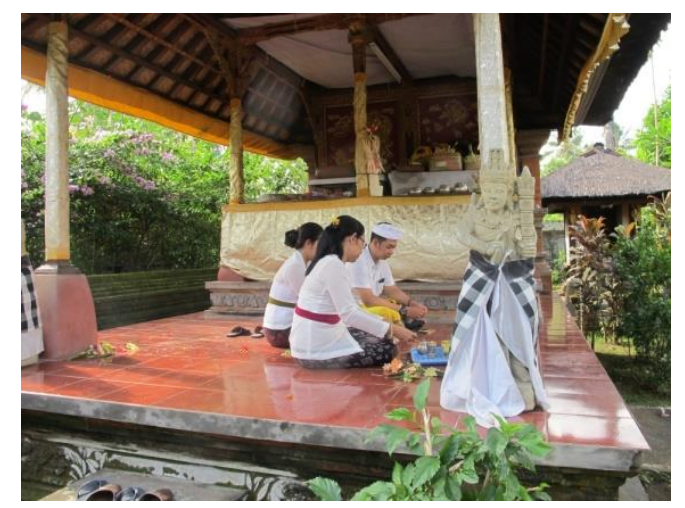

(Sumber: Dok. Penelitian, 2019)

Sang Bendesa Adat sempat mengutarakan bahwa adanya keinginan dalam dirinya untuk menjadikan Puri Sayan ini sebagai daya tarik wisata heritage karena dapat menjadi edukasi sejarah bagi para wisatawan. Bapak Tjokorda Gede menghuni Puri Sayan dengan istrinya dan dua pembantu Puri. Beliau memiliki keponakan yang seharusnya tinggal di Puri namun bekerja dan kini bertempat tinggal di pusat Kota Denpasar. Luas daripada Puri Sayan terasa hampa karena hanya berpenghuni empat orang termasuk Sang Bendesa Adat. Saat memasuki Puri Sayan akan terdapat jalan setapak yang apik nan indah menuju ke tiap-tiap ruangan yang ada di Puri Sayan itu sendiri. Terdapat beberapa bangunan termasuk diantaranya tempat tinggal, wantilan, dapur, dan juga Pura.
Gambar 3. Puri Sayan

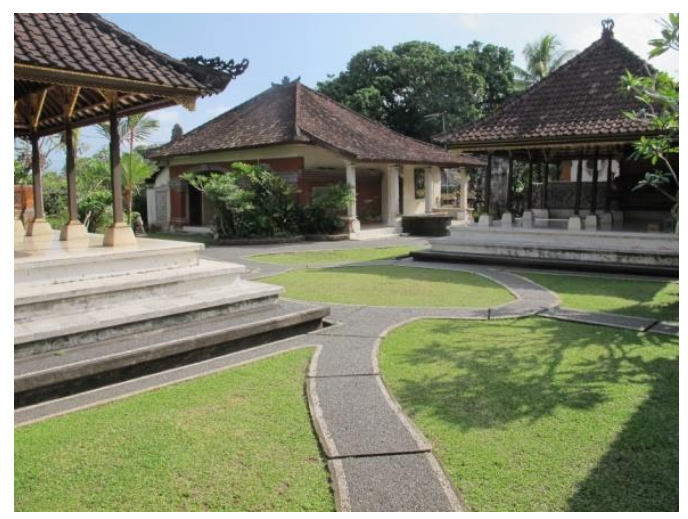

(Sumber: Dok. Penelitian, 2019)

Desa Sayan juga memiliki potensi budaya yang dapat dijadikan atraksi untuk dipasarkan kepada wisatawan khususnya mereka yang memiliki minat yang besar dengan kebudayaan Bali. Terdapat Karang Taruna yang merupakan kumpulan dari Sekaa Teruna Teruni tiap banjar di Desa Sayan yang mana mereka memiliki bakat sebagai penabuh gamelan. Tidak hanya Karang Taruna dan STT, kelompok masyarakat ibu-ibu PKK juga memiliki kegiatan rutin yaitu melatih anak-anak Tari Rejang secara turun-temurun. Hal ini juga tentunya merupakan potensi yang dapat dikembangkan sebagai atraksi di Puri Sayan. Menurut Ibu Made, ibu-ibu PKK setempat memiliki ikatan yang cukup kuat karena adanya pertemuan rutin setiap bulannya. Hal tersebut juga tidak dibatasi bahwa PKK tiap banjar pun biasa mengadakan pertemuan kapanpun sekiranya dibutuhkan. Kemudian terdapat pula Sekaa Selonding Pemudi dimana merupakan aktifitas penabuhan gamelan dari gadis remaja Banjar Kutuh.

Desa Sayan yang bergerak di sub sektor industri kecil atau kerajinan, didominasi oleh kerajinan pahat/ukiran kayu, sablon batik dan lukisan yang tersebar di beberapa Banjar. Bahkan beberapa di antaranya merupakan pionir di bidangnya seperti kerajianan pahat/ukiran kayu di Banjar Sindu yang belakangan mulai dikombinasikan dengan paket kerajinan alat musik atau Gambelan Tradisional Bali. Pariwisata sendiripun telah menjadi sub sektor penting bagi masyarakat Desa Sayan, potensi pariwisata Desa Sayan sudah terkenal ke seluruh Mancanegara. Desa Sayan sebagai salah satu tujuan wisata di Daerah Gianyar memiliki keunikan terutama karena kreativitas seni budaya (seni lukis dan pahat) dan potensi keindahan alamnya. Dalam bidang seni lukis, Desa Sayan memiliki seniman yang cukup dikenal seperti Ketut Soki, Ketut Tagen, Nyoman Cakra, Nyoman Tulus, Nyoman Sujana, dan yang lainnya. Dalam bidang seni pahat, Desa Sayan juga memiliki 
seniman ternama seperti Made Pacil, Wayan Sudira, dan yang lainnya. Tokoh dan perintis seni Desa Sayan tersebut telah mendapat pengakuan dan penghargaan baik dari dalam negeri maupun luar negeri.

Dalam segi potensi, Desa Sayan dapat dikatakan cukup memadai. Artinya memiliki potensi yang cukup untuk dijadikan atraksi wisata khususnya di Desa Sayan. Desa sayan memiliki penari-penari dan penabuh gamelan yang merupakan masyarakat Desa. Penabuh gamelan dari Desa Sayan pun turut mengikuti lomba Bale Ganjur dalam rangka HUT Kabupaten Gianyar pada April 2019. Desa Sayan juga memiliki pementasan calon arang versi hiburan yang mana tidak merupakan pementasan sakral seperti Pentas Calon Arang sesungguhnya. Hal ini tentunya dapat dijadikan atraksi di Puri Sayan jika ditinjau dari daya tarik pementasan Calon Arang yang menjadi cerita khas Bali. Desa Sayan juga memiliki upacara rutinan di Pura bernama Blaban Gedol yang dilakukan 2 tahun sekali.

Tidak hanya itu, Desa Sayan juga menjadi pencetus pertama adanya angklung di Ubud. Pementasan Angklung dengan iringan berbagai alat musik tabuhan atau gamelan yang lainnya ini mengiringi penari lepas yang sampai saat ini masih rutin dilakukan yaitu di Four Season, Sayan, Ubud. Septiani Putri sang penari lepas dengan iringan angklung dan gamelan ini berpendapat bahwa, keunikan daripada angklung Bali yang mengiringi Tarian lepas ini juga merupakan potensi atraksi yang sangat bagus karena dapat menjadi ciri khas daripada Desa Sayan.

\section{Accessibility}

Desa Sayan terletak di sebelah Barat Kecamatan Ubud yang mana hal ini membuat Desa Sayan menjadi sangat strategis karena merupakan pintu masuk sebelah Barat dari arah Kabupaten Badung. Akses menuju Desa Sayan dapat dikatakan cukup baik dan mudah. Kondisi jalan baik menuju ataupun di Desa Sayan itu sendiri sudah mulus dan memiliki lebar jalan yang cukup. Cukup dalam hal tidak terlalu besar dan tidak terlalu kecil dalam ukuran jalan raya di sebuah desa. Untuk menuju Desa Sayan dari pusat Kota Denpasar dapat ditempuh dengan estimasi waktu kurang lebih 50 menit menggunakan kendaraan roda dua, dan kurang lebih 60 menit jika menggunakan kendaraan pribadi roda empat. Tidak adanya lampu merah di Desa Sayan membuat suasana Desa masih dapat dikatakan cukup asri dan nyaman. Walaupun begitu, jarang ditemukan adanya kemacetan di Desa Sayan khususnya di Jalan Raya Sayan sebagai jalan utama Desa. Kondisi jalan internal Desa juga mulus dan baik. Tentunya aman bagi masyarakat, khususnya anak-anak yang suka bermain dijalanan.

Namun, sangat disayangkan informasi khusus menuju Desa Sayan kurang tersedia. Tentunya hal ini merupakan hal yang penting untuk mengembangkan pariwisata di Desa Sayan.. Walaupun sudah ada petunjuk arah menuju Desa Sayan, petunjuk arah di sekitar internal Desa juga dapat dikatakan minim jika dikatakan ingin dikembangkan menjadi Desa Wisata.

Gambar 4. Petunjuk Arah Desa Sayan

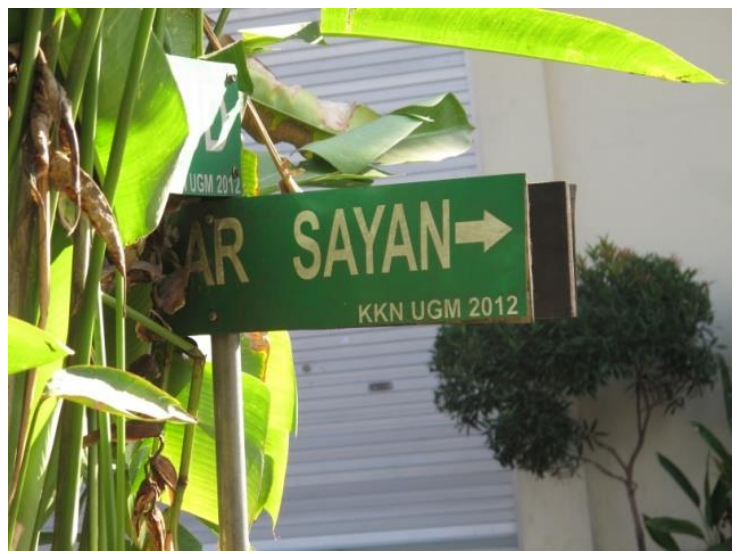

(Sumber : Dokumentasi Pribadi)

\section{Amenity}

Desa Sayan merupakan Desa Dinas yang terdiri dari 2 Desa Pakraman yaitu Desa Pakraman Penestanan dan Desa Pakraman Sayan. Saat ini pembangunan sarana pariwisata masih berat sebelah di Desa Sayan yakni hanya di Desa Pakraman Penestanan yang terdiri dari dua banjar yaitu Banjar Penestanan Kaja dan Banjar Penestanan Kelod. Pada kedua banjar tersebut kegiatan pariwisata sudah lebih dulu maju dikarenakan masyarakat lokal setempat telah membangun homestay di kediaman mereka masing-masing untuk menjadi pilihan akomodasi bagi wisatawan.

Gambar 5. The Samaya Luxury Villas

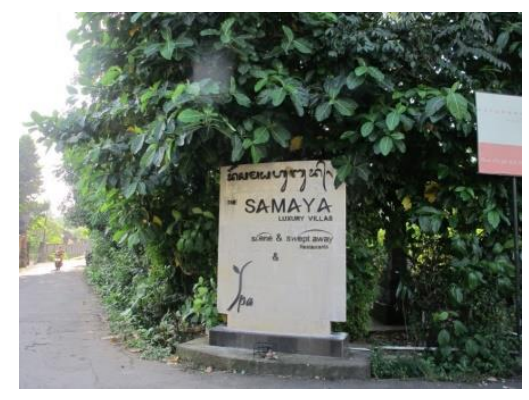

(Sumber : Dokumentasi pribadi) 
Walaupun sudah terdapat villa di Desa Sayan khususnya di bagian selatan bernama The Samaya Luxury Villas, namun villa tersebut bukanlah milik masyarakat melainkan milik swasta. Disana sudah ada beberapa kafe dan restaurant walaupun bukan milik masyarakat. Sementara Desa Sayan bagian selatan belum seramai wisatawan di bagian utara. Di Desa Sayan juga belum terdapat transportasi khususnya transportasi umum untuk menunjang kegiatan pariwisata di Desa Sayan. Namun untuk prasarana lain seperti tenaga listrik, persediaan air bersih, sudah terbilang normal dan baik. Bahkan Kantor Desa menyediakan sewa listrik bagi mereka yang ingin menggunakan listrik di pinggir jalan dekat Kantor Desa seperti neon box dan papan petunjuk arah atau lokasi tertentu.

\section{Ancillary}

Sebagai Desa Dinas di salah satu kecamatan yang cukup berkembang tentunya Desa Sayan memiliki kelembagaan baik dengan sistem formal maupun sistem informal didalamnya. Desa Sayan memiliki tujuan desa yaitu menjadikan Desa Sayan sebagai Desa Wisata. Adapun kelembagaan yang ada di Desa Sayan diantaranya adalah Desa Dinas Sayan, BUMDES Asta Dana Gantari, Badan Permusyawaratan Desa, Lembaga Pemberdayaan Masyarakat, KSU Desa, KSU Per Banjar, Linmas, POSYANDU, PKK Desa, STT per banjar, POSKAMLING, Lembaga Pengkreditan Desa, Karang Taruna, dan Kelompok Subak.

Dalam pengembangannya, Desa Sayan memiliki salah satu misi untuk mewujudkan Desa Sayan sebagai Desa Wisata. Tentunya untuk merealisasikan hal tersebut Desa Sayan memerlukan kelembagaan khusus untuk mengelola pariwisata di Desa Sayan, namun untuk saat ini hal tersebut belum ada. Pariwisata di Desa Sayan masih bergerak secara pribadi belum dapat saling berkesinambungan guna mewujudkan misi Desa Sayan menjadi Desa Wisata tersebut.

Hubungan antara kelembagaan desa dengan Puri Sayan belum cukup terlihat jika ditinjau dari kepentingan pariwisata. Dalam hal ini hubungan ditinjau dari kepentingan adat saja dikarenakan Bapak Bendesa Adat atau yang dalam hal ini merupakan pemilik dan penghuni daripada Puri Sayan. Dapat diketahui bahwa Puri Sayan berdiri sendiri dan pemerintah Desa Sayan ingin merencanakan Puri Sayan sebagai daya tarik wisata heritage yang nantinya Pemerintah Desa Sayan akan menjadi pengelolanya. Pengusaha pariwisata di Desa Sayan sendiripun belum ada yang mengambil peluang akan berpotensinya Puri Sayan sebagai daya tarik wisata heritage. Dalam hal ini masih adanya kekosongan dalam peran stakeholder pengusaha pariwisata jika dilihat untuk kepentingan Puri Sayan.

\section{B. Analisis SWOT komponen produk wisata heritage di Puri Sayan}

Untuk merencanakan Puri Sayan sebagai daya tarik wisata Heritage dipergunakan analisis SWOT (Strength, Weakness, Opportunities, and Threats). Dalam analisis ini akan dilihat segi kekuatan, kelemahan, peluang, dan ancaman di Desa Sayan yang mengacu pada komponen produk pariwisata 4A. Berikut hasil dari analisis tersebut.

\section{Kekuatan (Strenght)}

a. Potensi Atraksi (Attraction)

Puri Sayan memiliki potensi yang kuat diantaranya potensi fisik yaitu memiliki arsitektur bangunan yang unik bagaikan sedang berada masa lampau. Sebagai sebuah Puri, arsitektur daripada bangunan Puri Sayan sendiri tentunya terlihat sebagai peninggalan sebuah kerajaan yang tentunya hal ini sangat unik dan menjadi khas di Desa Sayan. Tidak hanya potensi fisik yang dapat terlihat saja (tangible) namun di Puri Sayan ini juga terdapat potensi non fisik seperti nilai sejarah Puri Sayan yang juga sebagai bagian dari Kerajaan Ubud.

Jika ditinjau potensi atraksinya, Desa Sayan memiliki lebih banyak dan potensi yang bervariasi. Dalam hal ini, tradisi dan kebudayaan masyarakat Desa Sayan setempat juga menjadi potensi atraksi yang dapat dikembangkan sebagai atraksi dalam Strategi dan program Puri Sayan sebagai daya tarik wisata heritage. Seperti sekaa selonding pemudi dimana merupakan aktifitas penabuhan gamelan dari gadis remaja banjar setempat. Kemudian ada pementasan calon arang yang diperankan oleh masyarakat setempat dengan memodifikasinya agar dapat ditonton secara umum. Selain itu juga terdapat tari lepas yang diiringi oleh gamelan dan angklung Bali dimana sejarah daripada angklung Bali tersebut pertama kali di Desa Sayan. Serta dalam sub sektor industri kecil Desa Sayan memiliki seniman ukir/pahat dan seniman lukis yang berpengalaman dan terkenal di mancanegara.

b. Aksesibilitas (accessibility)

Dari segi aksesibilitas lokasi Desa Sayan sendiri dapat dikatakan cukup strategis karena Desa Sayan sendiri merupakan salah satu Desa yang menyokong kepariwisataan di Kecamatan Ubud. Terletak di selatan Kecamatan Ubud, Desa Sayan menjadi salah satu akses utama untuk menuju pusat Ubud khususnya dari arah Abiansemal Kabupaten Badung. Tentunya untuk menuju ke pusat Ubud akan melewati Desa Sayan lebih tepatnya Banjar Penestanan Kaja dan Banjar Penestanan Kelod. Puri Sayan ini sendiri terletak di sebelah kanan dipinggir Jalan Raya Sayan seberang Banjar Pande jika dari arah selatan. Lokasi ini dapat dikatakan cukup 
strategis dan menjadi kekuatan tersendiri karena tidak memerlukan akses yang rumit untuk menuju Puri Sayan terlebih jika ditinjau dari Jalan Raya Sayan yang dapat dikatakan cukup bagus dan layak tentunya dapat menjadi keuntungan.

\section{Kelemahan (Weakness)}

\section{a. Amenitas (Amenity)}

Kelemahan di Desa Sayan dapat dilihat dari belum adanya pemerataan daripada fasilitas penunjang pariwisata di seluruh Banjar yang ada di Desa, kegiatan kepariwisataan hanya terjadi di Desa Pakraman Penestanan yaitu Banjar Penestanan Kaja dan Banjar Penestanan Kelod. Kurangnya akomodasi milik masyarakat Desa ini juga menjadi kelemahan daripada Desa Sayan karena untuk menunjang misi Desa Sayan untuk menjadi Desa Wisata baiknya masyarakat juga turut andil dan mengelola agar juga nantinya masyarakat akan mendapatkan hasil tidak hanya dari segi ekonomi namun juga interaksi dengan wisatawan. Di Desa Sayan juga masih kurang didapati puja sera atau tempat makan, transportasi dan juga petunjuk arah khususnya internal desa.

b. Kelembagaan (Ancillary)

Kelembagaan tentang kepariwisataan kurang memadai dan kurang menghimbau masyarakat mengenai pariwisata. POKDARWIS tidak merupakan sistem formal karena dihubungi secara fleksibel dan tidak resmi. Masyarakat cenderung biasa saja dengan pariwisata tanpa mengetahui betapa besar peluang Desa Sayan untuk berkembang menjadi daya tarik wisata. Karang Taruna yang merupakan generasi muda Desa Sayan seharusnya lebih cepat tanggap dengan hal pariwisata, jika memang ingin memajukan Desa Sayan menjadi Desa Wisata. Namun Karang Taruna setempat hanya terfokus dengan kegiatan remaja dan sosial saja bahkan hanya segelintir kelembagaan yang menganggap Puri Sayan layak untuk dirancang sebagai daya tarik wisata heritage.

\section{Peluang (Opportunities)}

\section{a. Aksesibilitas (Accessbility)}

Banyaknya wisatawan yang berkunjung ke Ubud kini, menjadi salah satu peluang yang cukup besar untuk Strategi dan program Puri Sayan sebagai daya tarik wisata heritage karena minat wisatawan yang berkunjung ke Ubud adalah karena kebudayaan dan tradisinya. Menurut Agung Indah, seorang travel guide wisatawan mancanegara di Ubud, kini wisatawan tersebut sedang maraknya mengikuti tour wisata budaya. Bahkan menurut perempuan berumur 21 tahun ini wisatawan mancanegara khususnya wisatawan yang berasal dari eropa sangat excited dengan wisata budaya dan menjadikan hal itu tren di kalangannya. Puri Agung
Ubud pun kini mengalami peningkatan kunjungan wisatawan yang tentunya hal ini memungkinkan besarnya peluang untuk menarik wisatawan ke Puri Sayan karena keterkaitannya dan hubungan sejarah yang kuat dengan Puri Agung Ubud. Selain itu, karena tingkat kemacetan yang cukup meningkat di Jalan Raya Pengosekan menjadi peluang tersendiri karena Desa Sayan dapat menjadi pilihan jalur alternatif bagi wisatawan yang ingin berkunjung ke pusat Ubud.

b. Kelembagaan (Ancillary)

Dalam pengembangannya pemerintah desa menginkan menjalankan program pemerataan kegiatan pariwisata di Desa Sayan agar seimbang dan tentunya mensejahterakan masyarakat lokal Desa Sayan. Hal ini juga merupakan peluang tersendiri dalam merencanakan Puri Sayan sebagai daya tarik wisata heritage.

\section{Ancaman (Threats)}

\section{a. Potensi Atraksi (Attraction)}

Potensi atraksi dari Puri Agung Ubud yang sudah terkenal yaitu setiap hari pada setiap malamnya sekitar pukul 19.00 WITA menjadi hal yang mengancam atraksi yang akan dirancang di Puri Sayan dikarenakan Puri Agung Ubud jauh lebih terkenal dibandingkan Puri Sayan.

b. Amenitas (Amenity)

Fasilitas penunjang di daya tarik serupa yakni Puri Agung Ubud sudah cukup memadai sementara di Puri Sayan baik di sekitar Desa Sayan maupun di Puri sendiri masih dapat dikatakan kurang adanya kelengkapan. Begitu banyaknya pilihan akomodasi disekitar Puri Agung Ubud juga menjadi suatu ancaman karena jika dilihat Desa Sayan sendiri belum memiliki akomodasi yang cukup di wilayahnya. Bahkan terdapat pula Puri Anyar Heritage sebagai akomodasi yang bernilai sejarah di pusat Ubud, sementara Puri Sayan belum menjadi apapun. 


\section{Strategi Puri Sayan sebagai Daya Tarik Wisata Heritage}

TABEL 1. MATRIKS ANALISIS SWOT

\begin{tabular}{|c|c|c|}
\hline & Strength (S) & Weakness (W) \\
\hline EFAS & $\begin{array}{l}\text { 1. Potensi Atraksi } \\
\text { Mempunyai ciri khas dan bervariasi seperti Kondisi } \\
\text { fisisk Puri Sayan yang bernilai sejarah tinggi, Sekaa } \\
\text { Selonding Pemudi, Pementasan Angklung, Blaban } \\
\text { Gedol, Tari lepas, dan Bale Ganjur dan juga Lontar } \\
\text { yang menjadi peninggalan dalam Puri. Serta dalam } \\
\text { sub sektor industri kecil Desa Sayan memiliki } \\
\text { seniman ukir//pahat dan seniman lukis yang } \\
\text { berpengalaman dan terkenal di mancanegara. } \\
\text { 2. Akssesibilitas } \\
\text { Letak Puri Sayan yang stratagis dan akses yang } \\
\text { memadai }\end{array}$ & $\begin{array}{l}\text { 1. Amenitas } \\
\text { Fasilitas penunjang kepariwisataan di Desa Sayan } \\
\text { belum merata dan kurangnnya kelengkapan seperti } \\
\text { puja sera attau tempat makan, transportasi, } \\
\text { petunjuk arah. } \\
\text { Belum adanya akomodasi 'milik masyarakatat. } \\
\text { 2. Ancillary } \\
\text { Kelembagaan tentang kepariwisataan masih } \\
\text { minim. Kurangnya penyuluhan dari pemerintah } \\
\text { Desa mengenai pariwisata }\end{array}$ \\
\hline Opportunities (0) & Strategi S-0 & Strategi W-0 \\
\hline 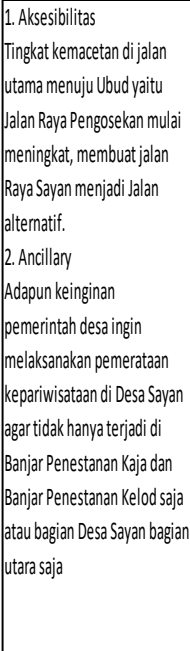 & 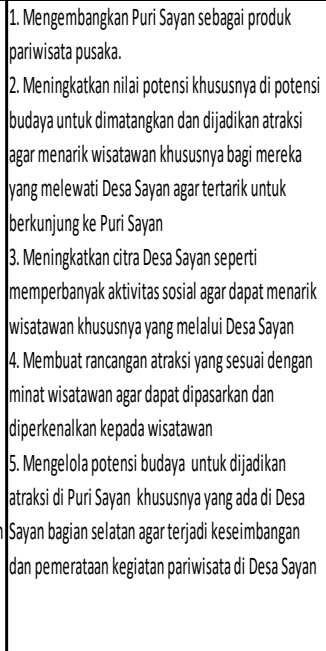 & 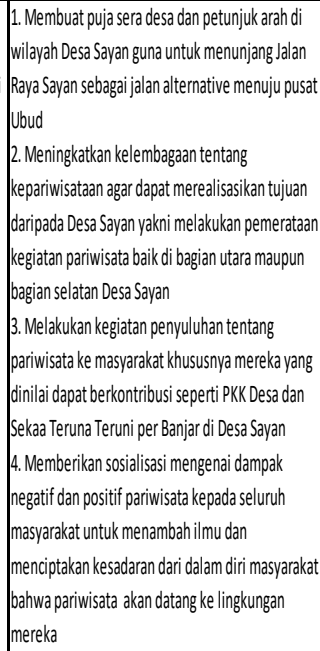 \\
\hline Threat (T) & Strategi S-T & Strategi W-T \\
\hline $\begin{array}{l}\text { 1. Potensi atraksi } \\
\text { Puri Agung Ubud juuh lebih } \\
\text { terkenal jika dibandingkan } \\
\text { dengan Pur Sayan. Hal ini } \\
\text { membuat minat wisatawan } \\
\text { untuk melihat atraksi i P Puri } \\
\text { Agunng Ubud cukuup besar } \\
\text { 2. Amenitas } \\
\text { Fasilitas penunjanng di daya } \\
\text { tarik serupa yaknn Puri Agung } \\
\text { Ubudd sudah cukup memadai } \\
\text { sementara di Puri Sayan } \\
\text { masih berupa desa biasa pada } \\
\text { umumnya }\end{array}$ & 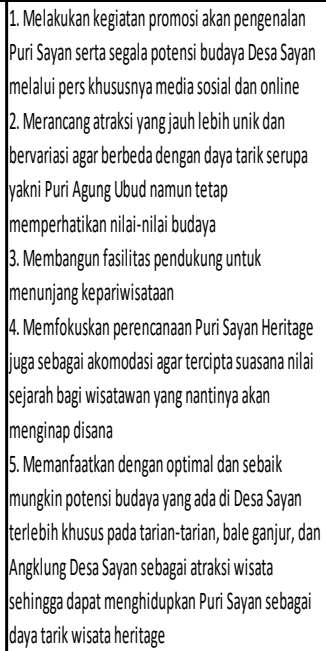 & 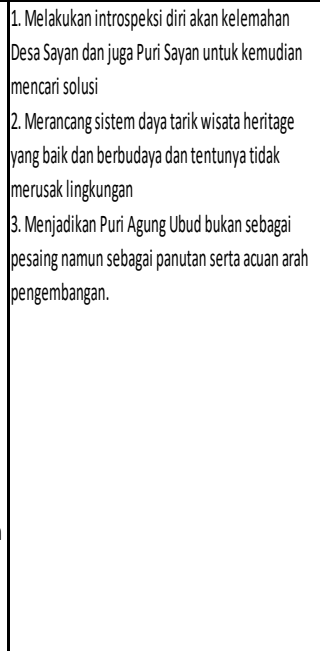 \\
\hline
\end{tabular}

(Sumber : Data yang diolah peneliti)
Berdasarkan analisis SWOT yang telah dilakukan di atas didapatkan beberapa strategi dan program yang yang dapat dilakukan dalam Strategi dan program Puri Sayan sebagai daya tarik wisata Heritage ditinjau dari peluang dan ancaman dengan penyesuaiannya terhadap kekuatan dan kelemahan yang dimiliki Desa Sayan sebagai berikut.

1. Strategi $\mathrm{S}-\mathrm{O}$

Strategi S-O dipakai dengan cara mengoptimalkan kekuatan yang dimiliki Puri Sayan di Desa Sayan dengan memanfaatkan peluang yang ada. Strategi S-O yang dimaksud adalah sebagai berikut: (a) Mengembangkan Puri Sayan sebagai produk pariwisata pusaka; (b) Meningkatkan nilai potensi khususnya di potensi budaya untuk dimatangkan dan dijadikan atraksi agar menarik wisatawan khususnya bagi mereka yang melewati Desa Sayan agar tertarik untuk berkunjung ke Puri Sayan; (c) Meningkatkan citra Desa Sayan seperti memperbanyak aktivitas sosial agar dapat menarik wisatawan khususnya yang melalui Desa Sayan; (d) Membuat rancangan atraksi yang sesuai dengan minat wisatawan agar dapat dipasarkan dan diperkenalkan kepada wisatawan; (e) Mengelola potensi budaya untuk dijadikan atraksi di Puri Sayan khususnya yang ada di Desa Sayan bagian selatan agar terjadi keseimbangan dan pemerataan kegiatan pariwisata di Desa Sayan.

\section{Strategi $\mathrm{W}-\mathrm{O}$}

Strategi W-O dihasilkan dengan memanfaatkan peluang yang ada dengan meminimalkan kelemahan. Adapun Strategi W-O yang dapat diuraikan sebagai berikut; (a) Membuat puja sera desa dan petunjuk arah di wilayah Desa Sayan guna untuk menunjang Jalan Raya Sayan sebagai jalan alternative menuju pusat Ubud; (b) Meningkatkan kelembagaan tentang kepariwisataan agar dapat merealisasikan tujuan daripada Desa Sayan yakni melakukan pemerataan kegiatan pariwisata baik di bagian utara maupun bagian selatan Desa Sayan; (c) Melakukan kegiatan penyuluhan ke masyarakat khususnya mereka yang dinilai dapat berkontribusi seperti PKK Desa dan Sekaa Teruna Teruni per Banjar di Desa Sayan.

\section{Strategi S-T}

Strategi S-T adalah strategi yang digunakan untuk mengatasi ancaman dengan memanfaatkan kekuatan yang dimiliki. Strategi S-T yang dihasilkan oleh analisis SWOT diatas adalah sebagai berikut: (a) Melakukan kegiatan promosi akan pengenalan Puri Sayan serta segala potensi budaya Desa Sayan melalui pers khususnya media sosial; (b) Merancang atraksi yang jauh lebih unik dan bervariasi agar berbeda dengan daya tarik serupa yakni Puri Agung Ubud namun tetap memperhatikan nilai-nilai budaya; (c) Membangun fasilitas pendukung untuk menunjang kepariwisataan; (d) Memfokuskan Strategi dan program Puri Sayan juga sebagai akomodasi agar tercipta suasana nilai sejarah bagi 
wisatawan yang nantinya akan menginap disana; (e) Memanfaatkan dengan optimal dan sebaik mungkin potensi budaya yang ada di Desa Sayan terlebih khusus pada tarian-tarian, bale ganjur, dan Angklung Desa Sayan sebagai atraksi wisata sehingga dapat menghidupkan Puri Sayan sebagai daya tarik wisata heritage.

4. Strategi $\mathrm{W}-\mathrm{T}$

Strategi W-T merupakan strategi yang dirancang secara defensive dengan meminimalkan kelemahan-kelemahan yang dimiliki dan menghindari ancaman. Strategi $\mathrm{W}$-T yang dimaksud adalah sebagai berikut: (a)elakukan introspeksi diri akan kelemahan Desa Sayan dan juga Puri Sayan untuk kemudian mencari solusi; (b) Merancang sistem daya tarik wisata heritage yang baik dan berbudaya dan tentunya tidak merusak lingkungan;(c) Menjadikan Puri Agung Ubud bukan sebagai pesaing namun sebagai panutan serta acuan arah pengembangan.

\section{Program Puri Sayan sebagai Daya Tarik Wisata Heritage \\ Dengan melihat analisis SWOT dalam} merumuskan strategi Puri Sayan sebagai daya tarik wisata heritage di Desa Sayan yang mengacu pada komponen produk pariwisata $4 \mathrm{~A}$ yang telah dilakukan, maka dapat disusun program dalam Strategi dan program Puri Sayan sebagai daya tarik wisata heritage yaitu sebagai berikut: (1) Program Jelajah Puri Sayan, program ini dilakukan dengan memanfaatkan kondisi fisik Puri Sayan yang bernilai sejarah tinggi maka dapat dibuat program "Jelajah Puri Sayan" yang mana dalam program ini atraksi utamanya adalah mengelilingi Puri Sayan sambil mengenal dan merasakan suasana sejarah dimana Puri Sayan merupakan Pada program ini Puri Sayan akan dijadikan miniatur daripada Desa Sayan dimana nantinya ditampilkan semua potensi di Desa Sayan sebagai atraksinya. Dalam Jelajah Puri Sayan ini, wisatawan dapat menikmati atraksi yang ditawarkan dari sehabis makan siang hingga menjelang matahari terbenam. Tentunya pada program ini Puri Sayan memiliki keunggulan dimana tidak adanya tawaran atraksi serupa yakni jelajah puri pada daya tarik wisata serupa yaitu Puri Agung Ubud; (2) Program Puri Sayan Night Show, kegiatan memasarkan Puri Sayan sesuai dengan minat wisatawan yaitu menyukai hal-hal yang unik dan menarik. Maka dapat dibuat program atraksi di Puri Sayan yang ditampilkan berbeda 3 hari dalam seminggu, yakni senin rabu jum'at dan tentunya libur saat Hari Raya Umat Hindu. Hal ini dilakukan dengan memanfaatkan potensi budaya di Desa Sayan seperti Tari Lepas dengan iringan Angklung, Pementasan Calon Arang (hiburan), penampilan Bale Ganjur serta Sekaa Selonding Pemudi sebagai atraksinya; (3) Program Bali's Culture Learning
Class, program ini merupakan program dimana akan mempelajari budaya Bali di Puri Sayan, dengan membuat wantilan Puri sebagai kelas diantaranya kelas mempelajari kaidah Lontar, kelas menari Tarian Bali, kelas melukis dan memahat dengan digurui oleh seniman lukis dan seniman pahat dari Desa Sayan yang sudah terkenal dan berpengalaman, dan dengan diiringi oleh pagelaran musik gamelan yang ditampilkan oleh Karang Taruna Desa Sayan kepada wisatawan; (4) Program Jumat Bersih, dalam program ini akan dihimbau bagi pengelola Puri Sayan yang akan dibentuk yakni tergabung dalam perwakilan dari pihak desa, POKDARWIS, Karang Taruna, STT Banjar setempat, serta PKK Desa, untuk melakukan pembersihan pekarangan dan lingkungan Puri, mengganti dan menambahkan fasilitas toilet, serta menyediakan bahan-bahan dapur yang telah habis. Program ini diadakan guna untuk menciptakan kenyamanan bagi wisatawan yang nantinya akan berkunjung ke Puri Sayan; (5) Program Festival "Living in Culture and Nature of Sayan", untuk menyokong Desa Sayan menjadi Desa Wisata maka dapat disusunlah program ini yaitu, mengadakan festival dengan tema "Living in Culture and Nature of Sayan" dimana 3 potensi utama di Desa Sayan yakni Wisata Alam Bija, dan Water Tubbing akan dijadikan atraksi dalam Festival ini. Festival ini akan menjadikan Puri Sayan sebagai akomodasi bagi wisatawan yang nantinya akan melakukan kegiatan cycling di jalur trekking wisata alam bija dan water tubbing; (6) Program Sosialisasi Pariwisata, dalam program ini dilakukan penyuluhan dan sosialisasi kepada masyarakat lokal Desa Sayan mengenai Pariwisata serta bagaimana dampak negatif dan positif yang diakibatkannya. Dengan hal ini maka masyarakat akan aware dan tentunya diharapkan akan berpartisipasi untuk ikut mengambil keputusan dalam setiap kegiatan pariwisata yang dilakukan khususnya di Desa Sayan; (7) Program Pengelolaan, dalam merencanakan Puri Sayan sebagai daya tarik wisata heritage tentunya dibutuhkan pengelola untuk mengembangkannya. Tentunya POKDARWIS saja tidak cukup, maka dari itu pihak desa perlu membuat suatu kelompok masyarakat yang terkhusus untuk mengelola Puri Sayan. Dalam Pengelolaannya, Puri Sayan juga dapat dijadikan sebagai akomodasi bagi wisatawan. Akomodasi dengan jumlah kamar terbatas dan suasana dengan nilai sejarah dan budaya yang tentunya sangat berbeda dari akomodasi pada umumnya; (8) Program Promosi, untuk menyetarakan diri dengan Puri Agung Ubud dalam sisi terkenal dikalangan wisatawan, tentunya diperlukan kegiatan promosi yang gencar, maka dari itu dapat dibuat program "Promosi" yaitu dengan memanfaatkan era digital masa kini maka dilakukan kegiatan promosi melalui media sosial, pers, juga 
web resmi Desa Sayan. Mereka yang melakukan kegiatan promosi ini adalah pengelola Puri Sayan yang telah dibentuk dan juga tentunya masyarakat yang telah diberi penyuluhan ataupun sosialisasi mengenai pentingnya pariwisata: (9) Program Informasi dan Petunjuk Arah, program ini ditujukan kepada pihak pemerintah Desa untuk membangun petunjuk arah menuju Puri Sayan agar Puri Sayan sudah dapat diketahui oleh wisatawan dari perjalanan. Petunjuk arah dibangun kira-kira dari 500 m, 100m, dan 20m sebelum Puri Sayan, baik dari arah utara maupun selatan. Kemudian membangun posko informasi untuk wisatawan yang kebingungan yang nantinya dapat diarahkan menuju Puri Sayan atau bahkan daya tarik wisata lainnya di Desa Sayan.

\section{KESIMPULAN}

Adapun simpulan yang dapat diambil dari hasil penelitian yang berjudul "Strategi dan program Puri Sayan sebagai Daya Tarik Wisata Heritage" yaitu dapat diketahui bahwa Puri Sayan memiliki banyak potensi tangible maupun intangible yang dapat dikembangkan sebagai daya tarik wisata khususnya dalam hal ini wisata heritage. Potensi ini menjadi kekuatan yang dimiliki Puri Sayan sehingga memungkinkan Puri Sayan untuk dijadikan daya tarik wisata heritage. Dalam analisis SWOT yang dilakukan dapat dirumuskan beberapa strategi dalam Strategi dan program Puri Sayan sebagai daya tarik wisata heritage. Strategi tersebut menjadi acuan dalam perancangan program yang dihasilkan sebagai berikut : (1) Program Jelajah Puri Sayan (2) Program Puri Sayan Night Show (3) Program Bali's Culture Learning Class (4) Program Jumat Bersih (5) Program Festival "Living in Culture and Nature of Sayan" (6) Program Sosialisasi Pariwisata (7) Program Pengelolaan (8) Program Promosi (9) Program Informasi dan Petunjuk Arah.

\section{DAFTAR PUSTAKA}

Anonym, 2009. Undang - undang Republik Indonesia No. 10 tentang Kepariwisataan.

Agung, Ida Bagus. 2010. Strategi Pengembangan Puri Agung Karangasem sebagai Daya Tarik Wisata Budaya di Kabupaten Karangasem. Bali: Fakultas Pariwisata. Universitas Udayana.

Agung, Anak Agung Gde Putra. 2001. Peralihan Sistem Birokrasi Kerajaan Karangasem dari Tradisional ke Kolonial.Yogyakarta : Pustaka Belajar.

Arthanovia, Ratih. 2019. Strategi dan program Puri Sayan sebagai daya tarik wisata heritage di Desa Sayan, Kecamatan Ubud, Kabupaten Gianyar, Bali. Penelitian Lapangan III.
Fakultas Pariwisata. Universitas Udayana. Denpasar.

Bajra, Ida Bagus. 2017. Selayang Pandang Pura Persimpangan Ulundanu.Bali: Giriya Gunung Payangan.

Bungin, Burhan. 2003. Analisis Data Penelitian Kualitatif. Jakarta : PT Grafindo Persada

Cooper, dkk. 1995. Tourism, Principles and Practice. Prentice Hall: Harlow

Erly Suandy, 2001. Strategi dan program Pajak . Salemba Empat : Jakarta

Hariyana, I. K., \& Mahaganggaa, I. G. A. O. (2015). Persepsi Masyarakat Terhadap Pengembangan Kawasan Goa Peteng Sebagai Daya Tarik Wisata Di Desa Jimbaran Kuta Selatan Kabupaten Badung. Jurnal Destinasi Pariwisata ISSN, 2338, 8811.

Hidayat, Marceilla. 2011. Strategi Pengembangan Objek Wisata (Studi Kasus Pantai Pangandaran Kabupaten Ciamis Jawa Barat). Politeknik Negeri Bandung

Inskeep, E. 1991. Tourism Planning; An Integrated and Sustainable Development Approach, Van Nostrand Reinhold

Laksana, Dinov Sambadi Adistria. 2018. Strategi Pengemasan Wisata Heritage Di Desa Wisata Kerta, Kecamatan Payangan, Kabupaten Gianyar, Bali. Bali: Fakultas Pariwisata Universitas Udayana

Moleong, Lexy J. 2007. Metodologi Penelitian Kualitatif. Bandung : Remaja Rosdakarya.

Pendit, Nyoman .S. 1999. Ilmu Pariwisata. Jakarta : Akademi Pariwisata Trisakti.

Rangkuti, Freddy. 2003. Analisis SWOT Teknik Membedah Kasus Bisnis. Jakarta: Penerbit PT Gramedia Pustaka Utama.

Spillane J.J. 1987. Pariwisata Indonesia Sejarah dan Prospeknya. Yogyakarta : Kanisius.

Sugiyono. 2007. Memahami Penelitian Kualitatif. Bandung. Alfabeta.

Syafi'i, Muhammad dan Djoko Suwandono. 2015. Strategi dan program Desa Wisata Dengan Pendekatan Konsep Community Based Tourism (CBT) Di Desa Bendono, Kecamatan Sayung, Kabupaten Demak. Universitas Dipenogoro Semarang. 
Taolin, Arichtia Praevianti. 2016. Potensi Heritage yang dimiliki oleh Desa Wisata Tamkesi Kabupaten Timor Tengah Utara sebagai Daya Tarik Wisata. Jurnal Destinasi Pariwisata. Universitas Udayana.

Wiguna, Putu Aditya Dharma Arya. 2018. Strategi Pengembangan Potensi Desa Wisata Di Desa Wisata Kerta, Kecamatan Payangan, Kabupaten Gianyar, Bali. Bali: Fakultas Pariwisata Universitas Udayana

Yoeti, O.A. 2008. Strategi dan program \& Pengembangan Pariwisata. Jakarta: PT Pradnya Paramita

Yoeti, O. A. 2006.Pariwisata Budaya Masalah dan Solusinya. Jakarta: PT Pradnya Paramita

http://www.desasayanubud.com (Diakses pada tanggal 19 April 2019) 